\title{
Promoting private sector engagement in climate change adaptation and flood resilience: A case study of innovative approaches applied by MSMEs in Mumbai, India.
}

\author{
Schaer, Caroline; Pantakar, Archana
}

Published in:

Theory and Practice of Climate Adaptation

Link to article, DOI:

10.1007/978-3-319-72874-2_10

Publication date:

2018

Document Version

Peer reviewed version

Link back to DTU Orbit

Citation (APA):

Schaer, C., \& Pantakar, A. (2018). Promoting private sector engagement in climate change adaptation and flood resilience: A case study of innovative approaches applied by MSMEs in Mumbai, India. In Theory and Practice of Climate Adaptation (pp. 175-191). Springer. Theory and Practice https://doi.org/10.1007/978-3-319-728742_10

\section{General rights}

Copyright and moral rights for the publications made accessible in the public portal are retained by the authors and/or other copyright owners and it is a condition of accessing publications that users recognise and abide by the legal requirements associated with these rights.

- Users may download and print one copy of any publication from the public portal for the purpose of private study or research.

- You may not further distribute the material or use it for any profit-making activity or commercial gain

- You may freely distribute the URL identifying the publication in the public portal 


\section{Promoting private sector engagement in climate change adaptation and flood resilience - A case study of innovative approaches applied by MSMEs in Mumbai, India.}

\begin{tabular}{|l|l|} 
Caroline Schaer $(\mathrm{PhD})$ & Archana Pantakar $(\mathrm{PhD})$ \\
UNEP DTU Partnership & MP Ensystems Advisory Pvt. Ltd. \\
Marmorvej 51 & Ground Floor, Dwarka, Pushpadhanwa Society \\
2100 Copenhangen $\varnothing$ & Madan Mohan Malaviya Road, Mulund (West) \\
Denmark & Mumbai 400080 \\
E-mail address: $\underline{\text { cesc@,dtu.dk }}$ & India \\
Tlf.: +4593511611 & E-mail address: $\underline{\text { archana@mpensystems.com. }}$. \\
& Tlf.: +91.98205.01438 \\
\hline
\end{tabular}

Recurring heavy precipitation and flooding cause extensive loss and damage in cities like Mumbai. Among the worst affected are Micro Small and Medium Enterprises (MSMEs) which suffer damage to physical structure and loss of business. These costs amount to millions of dollars and are borne by MSMEs in the absence of adequate insurance protection. With limited flood management services and inadequate infrastructure provided by the municipal authorities, MSMEs are implementing their own temporary measures for flood protection. These are often ineffective during heavy precipitation and create risks of maladaptation. As climate change is expected to worsen the risk of flash floods with changes in intensity, frequency and duration of rainfall, MSMEs need long-term solutions to build their adaptive capacity and resilience.

This paper describes the business case for private sector engagement in flood risk reduction and climate adaptation from the perspective of MSMEs in Mumbai. Based on extensive field surveys of MSMEs located in industrial estates, the paper discusses the implications of floods for MSMEs. Moreover, the authors present a framework developed for MSMEs to make informed risk reduction and adaptation decisions and implement effective structural and non-structural measures to minimize the recurring adverse impacts of floods on their business operations.

\section{Introduction}

It is broadly acknowledged that floods, droughts, sea level rise and increased variability of weather patterns are increasingly and disproportionately affecting vulnerable regions, with the least capacity to tackle the manifestations of a changing climate (IPCC, 2014). In 2014, 87 per cent of disasters were climate-related (UNHABITAT 2016) and cities in developing countries are particularly and increasingly at risk. Due to a combination of physical exposure, increase in extreme event occurrence, rapid urban growth, poor urban planning, inadequate basic infrastructure and disaster preparedness, the implications in urban centers for households, businesses and the economy as whole are widespread (UNHABITAT 2016). By 2070, populations and assets in Asian cities, particularly in India, China and Thailand, are expected to be among the most exposed to coastal flooding, as a result of the rapid urbanization and economic growth projected in these countries (Nicholls et al., 2008).

This poses important challenges for the planning, financing and implementation of climate change adaptation measures, which has traditionally been considered as the sole responsibility of the public sector. Yet, global estimates show that the costs of adaptation in developing countries 
- which are estimated to rise to US\$ 500 billion by 2050 (UNEP, 2016) - will considerably surpass the public sector's financial resources. As a result, both public and private stakeholders are key to contribute to build climate-resilient societies (Dougherty-Choux et al., 2015). The private sector is thus increasingly recognized as critical to progress in adaptation, given its unique expertise, its capacity to innovate and produce new technologies, its financial leverage and its role in scaling up adaptation of communities, as well as in managing risk information (IPCC, 2014). Harnessing the private sector's role in developing countries will thus be essential to help communities adapt to climate change.

Previous literature has mainly concentrated on companies' mitigation actions, while failing to give sufficient attention to their adaptation strategies (Okereke et al., 2012). Although studies on private sector adaptation have started to emerge the last 10 years (Linnenluecke et al., 2012; Agrawala et al., 2011;United Nations Global Compact, 2015; Wedawatta et al., 2010; Haigh \& Griffiths, 2012; Okereke et al., 2012; Berkhout, Hertin, \& Gann, 2006), these are largely limited to developed countries. In addition, while it is increasingly acknowledged that the private sector has an essential role to play in supporting societal resilience to climate change impacts and addressing the risks and opportunities posed by a changing climate, to date research has mainly focused on large multinational corporations (MNCs), private investors, and how they may contribute to close the gap in adaptation finance. Hence, current literature on private sector engagement only covers a fraction of the global private sector.

Thus far, little is therefore known on the role that Micro, Small and Medium sized Enterprises (MSMEs) $^{1}$ can play in relation to climate change adaptation in developing countries. Not only do MSMEs constitute more than $90 \%$ of businesses in developing countries (Hussain et al., 2012) and are thus contributing significantly to employment generation and supporting livelihoods, they also have a lower technical and financial capacity to respond to climate and disaster risks, and are therefore disproportionately affected by the negative impacts of climate change. MSMEs do for example not operate within the same planning timeframe as bigger companies, and do not necessarily have the needed climate information available nor the same incentives to implement risks minimization measures (United Nations Global Compact, 2015). And even in cases and cities where climate information is accessible and risk awareness is high, there are few tools available for identifying, analyzing and selecting location and time-specific adaptation measures (Dougherty-Choux et al., 2015).

Acknowledging the significance and potential of MSME engagement in adaptation is thus essential and is receiving increasing attention in the international arena. However, the literature in the field is relatively under-developed and empirical evidence sparse. Beyond sector specific or firm-specific studies, the literature mainly presents broad conceptual insights and general recommendations, and only goes so far as to emphasize the gap between the need to improve MSME resilience and the existing knowledge on the issue.

This paper seeks to contribute to address these gaps by exploring the business case for adaptation engagement in the context of MSMEs in Mumbai, which are among the worst affected by heavy precipitation and flooding every year. This paper presents key results from a UNEP DTU

\footnotetext{
${ }^{1}$ MSMEs are defined here as, 'micro enterprises: 1-9 employees; small: 10-49 employees; and medium: 50-249 employees' (IFC 2010). However, it is important to note that often times this definition is inconsistent with the realities on the ground, and local definitions should take precedence.
} 
Partnership supported initiative - the Admire project ${ }^{2}$ - which aims at introducing innovative approaches to enhance MSMEs' adaptation capacity and support their flood resilience efforts.

The paper starts by presenting the causes and effects of recurrent flooding in Mumbai and the rationale for a focus on MSMEs. Subsequently, the methodology applied in the study is described followed by a depiction of MSMEs profile in Mumbai and owners' views on floods and risk management. The subsequent section presents an innovative and context specific framework developed to assess risks and facilitate MSMEs' flood resilience efforts and help actors make informed risk reduction and adaptation decisions.

\section{Flood risk (mis)management in Mumbai - causes, effects and prospects for SMEs}

The city of Mumbai is highly vulnerable to climate change impacts such as flooding, cyclones, sea-level rise and coastal erosion, due to its low-lying location on a peninsula, which is poorly drained and built on reclaimed land, mainly composed of landfill (Patankar \& Patwardhan, 2016; Schiller et al., 2007). Flooding is thus a chronic and recurrent problem in the city due to tidal variations, flat gradients and mud flats causing excessive siltation (MCGM, 2014). Mumbai experiences severe events on a yearly basis, with the unprecedented 2005 floods as the most severe example, which caused damages estimated at USD 1.7 billion and 500 casualties (Ranger et al. 2011). Historically, during the monsoon season between June and October, the city experiences average rainfall surpassing 2200mm (MCGM 2015). Since 2001, this average has increased to $2400 \mathrm{~mm}$, with variations from the lowest of $1274 \mathrm{~mm}$ to highest of $3378 \mathrm{~mm}$ (MCGM, 2015). The frequency, duration and intensity of rainfall and flooding have also changed over the years. Combined with other drivers of risk such as uncontrolled urban growth, encroachment of natural water ways, poor disaster risk management governance and inadequate drainage systems, this causes significant adverse consequences for public and private stakeholders. These include loss of property and livelihoods, disruption of economic and social activities, poor health, damage to public and private infrastructure etc.

In Mumbai, MSMEs constitute an important part of the local and regional economy and provide substantial employment opportunities to semi-skilled and unskilled workforce. These businesses have faced increasing risks and multiple vulnerabilities and future climate change is expected to worsen these risks further by changing the intensity, frequency and duration of rainfall over the city (Field et al., 2012). Although they suffer from the impacts of recurrent flooding, in the form of damages to physical structure and loss of business, this sector has traditionally been neglected in disaster risk management planning and formal post flood loss assessments. The costs incurred are typically borne by MSMEs alone in the absence of adequate insurance protection. Neither the local government nor industry associations representing MSMEs have attempted to assess the flood impacts on MSMEs in Mumbai or to suggest long-term measures for building flood resilience. While many businesses in India - including MSMEs - are increasingly initiating mitigation measures, for example to improve energy efficiency, MSMEs do not yet consider climate risks as business as usual in order to deal with the direct and indirect impacts of climate change, by 'climate proofing' their businesses (GIZ \& SIDBI, 2013).

\footnotetext{
${ }^{2}$ The ADMIRE Project is implemented in 14 countries worldwide and aims at developing commercially viable operational and financial frameworks engaging the private sector in climate mitigation and/or adaptation actions. http://www.admireproject.org
} 


\section{Methodology and study area}

The study was carried out in three stages. First, a baseline mapping was undertaken to understand flood impacts, current responses undertaken by MSMEs and the attitudes of MSME owners and local actors. Secondly, suitable adaptation measures were designed based on relevant parameters for industrial estates; and lastly a framework was developed to provide guidance for MSMEs on designing, financing and implementing the suggested measures. The methodology used at each stage is described in Table 1.

Table 1: Research methodology

\begin{tabular}{|c|c|c|c|}
\hline Objective & Research questions & Methodology & Data sources \\
\hline $\begin{array}{l}\text { Baseline } \\
\text { mapping }\end{array}$ & $\begin{array}{l}\text { - Nature, frequency and } \\
\text { depth of flooding in the } \\
\text { selected study area } \\
\text { Exposure to recurrent } \\
\text { floods, impacts on } \\
\text { MSMEs and monetary } \\
\text { value of damages } \\
\text { - Current coping } \\
\text { mechanisms for flood } \\
\text { protection } \\
\text { Relationship with local } \\
\text { government and other } \\
\text { stakeholders }\end{array}$ & $\begin{array}{l}\text { Land use mapping of study } \\
\text { area to identify location of } \\
\text { industrial estates vis-à-vis } \\
\text { flooding spots } \\
\text { Primary surveys in randomly } \\
\text { selected MSMEs and industrial } \\
\text { estates in study area } \\
\text { - Mapping of current structures } \\
\text { and associations of MSMEs } \\
\text { Consultations with relevant } \\
\text { stakeholders }\end{array}$ & $\begin{array}{l}\text { Base maps of study } \\
\text { area available with } \\
\text { Municipal Corporation } \\
\text { of Greater Mumbai } \\
\text { (MCGM) } \\
\text { GIS-based maps } \\
\text { created using base } \\
\text { maps to indicate } \\
\text { location of MSMEs } \\
\text { and flooding spots } \\
\text { Available databases on } \\
\text { MSMEs with contact } \\
\text { details and nature of } \\
\text { business }\end{array}$ \\
\hline $\begin{array}{l}\text { Designing } \\
\text { suitable } \\
\text { adaptation } \\
\text { measures }\end{array}$ & 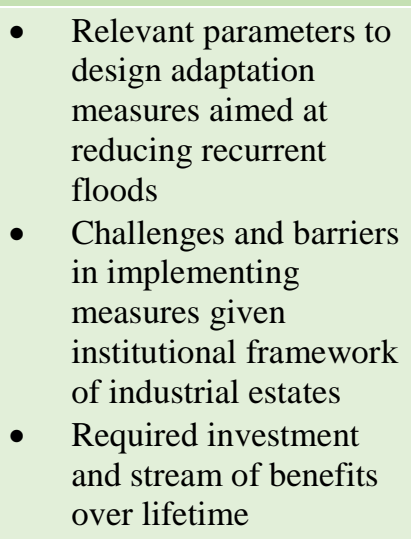 & $\begin{array}{l}\text { Consultations with industrial } \\
\text { estate representatives and site } \\
\text { visits to identify relevant } \\
\text { parameters } \\
\text { Identification and design of } \\
\text { suitable hard (structural) and } \\
\text { soft (non-structural) adaptation } \\
\text { measures based on parameters } \\
\text { Evaluation of investment } \\
\text { requirements for identified } \\
\text { measures vis-à-vis benefits } \\
\text { over their lifetime }\end{array}$ & $\begin{array}{ll}\text { - } & \text { Consultations with } \\
\text { industrial estate } \\
\text { representatives } \\
\text { - } \quad \text { Literature review on } \\
\text { private sector } \\
\text { adaptation initiatives } \\
\text { - Site visits to identify } \\
\text { technical parameters } \\
\text { Cost-benefit analysis } \\
\text { tool prepared by DTU } \\
\text { experts }\end{array}$ \\
\hline $\begin{array}{l}\text { Sustainable } \\
\text { operational and } \\
\text { financial } \\
\text { framework }\end{array}$ & $\begin{array}{l}\text { Step-by-step guidelines } \\
\text { required for industrial } \\
\text { estates to design and } \\
\text { implement adaptation } \\
\text { measures } \\
\text { Available options for } \\
\text { financing of selected } \\
\text { measures }\end{array}$ & $\begin{array}{l}\text { Preparation of robust } \\
\text { operational framework with } \\
\text { clearly defined roles and } \\
\text { responsibilities for MSMEs and } \\
\text { their industrial estate } \\
\text { cooperative societies } \\
\text { Identification of suitable } \\
\text { financing options }\end{array}$ & $\begin{array}{l}\text { Designs prepared by } \\
\text { experts based on } \\
\text { relevant parameters } \\
\text { - } \quad \text { Excel toolkit to input } \\
\text { parameter values and } \\
\text { - } \quad \text { Investment outlays } \\
\text { estimated for different } \\
\text { measures } \\
\text { Consultations with } \\
\text { banking and insurance }\end{array}$ \\
\hline
\end{tabular}




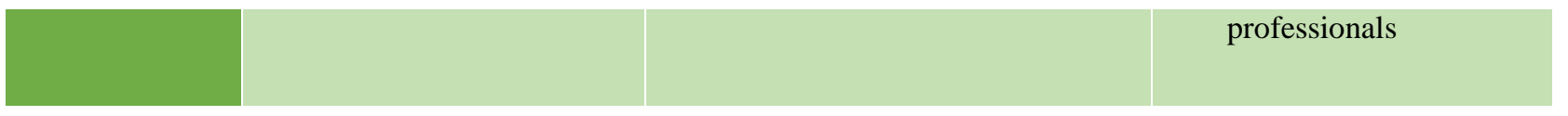

In order to create a baseline for flood impacts on industrial estates and their current responses, ' $\mathrm{L}$ ward ${ }^{3}$ representing a typical mixed land use prone to chronic flooding has been selected as the study area. L ward is prone to chronic flooding since it is located in the floodplain of Mithi River, which experiences severe floods during rainy season each year. Five chronic flooding spots in the study area have been selected for the questionnaire-based primary surveys among randomly selected MSMEs and industrial estates. The map of L ward with existing land use and location of flooding spots is given as Figure 1 below. Circled areas are chronic flooding spots identified by the local government (MCGM) and purple areas denote industrial estates. The total area of the ward is 15.56 sq. km., out of which $38.69 \%$ is used for residential, $3.74 \%$ for commercial and 12.76\% for industrial establishments (MCGM, 2014).

\footnotetext{
${ }^{3}$ For administrative purposes, Mumbai city is divided into 24 zones known as 'wards'. L ward is located in the Eastern suburbs of the city
} 


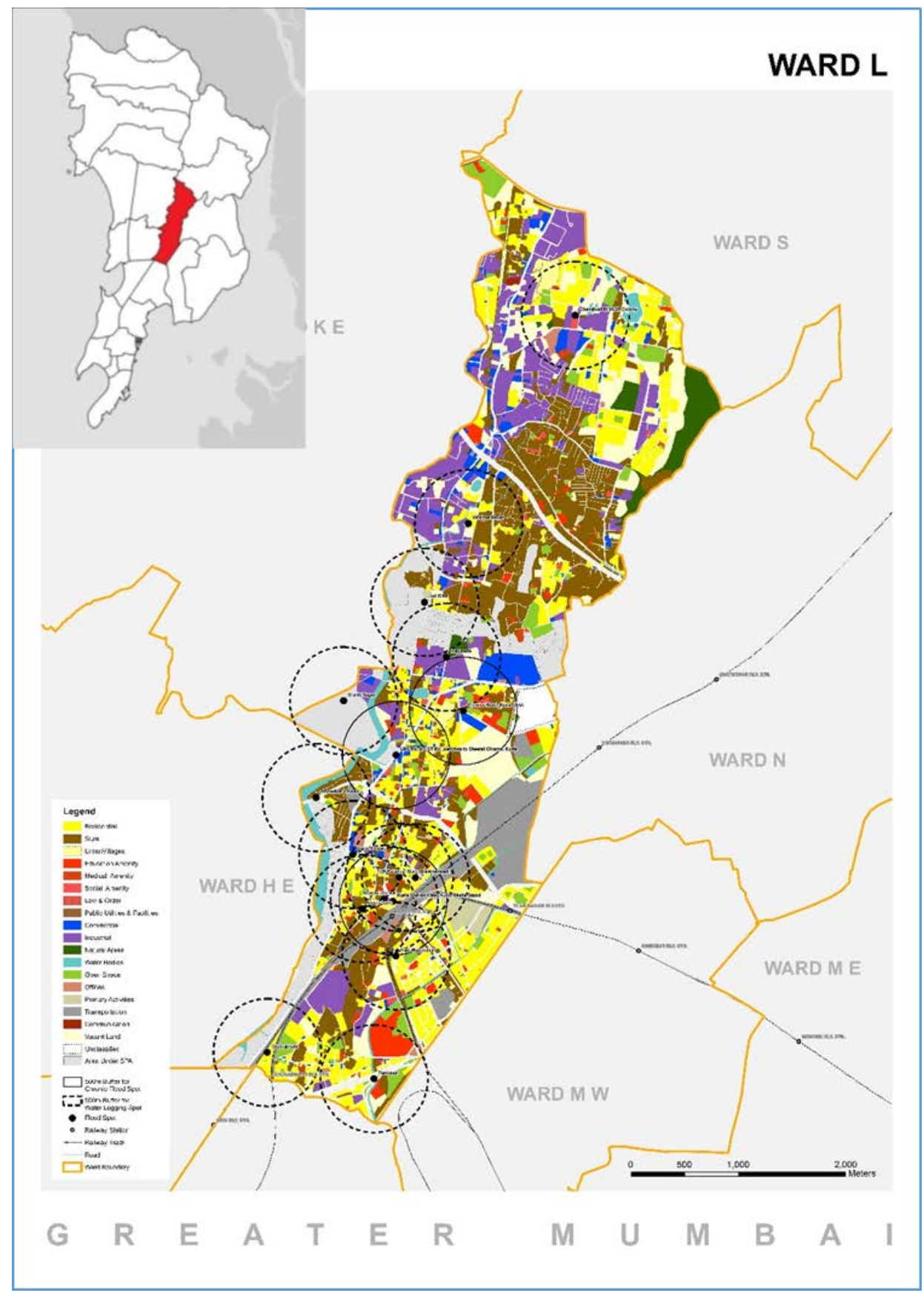

Source: GIS-based maps created for the study

Figure 1: Map of study area with depicting land use and flooding spots

100 MSME units were administered detailed questionnaires focusing on exposure to recurrent floods, associated damage costs and current response measures. These included questions related to MSME business profiles in industrial estates, structural characteristics, location and maintenance of the premises. Moreover, specific questions addressed the frequency, depth of flooding and types of damage to business premises, infrastructure, equipment and products. The survey further captured information on the indirect and direct costs of flood events, the current 
measures applied to combat floods and their effectiveness and the respondents' willingness to pay for long-term flood resilience services.

In addition to MSME unit surveys, interviews were conducted with 15 industrial estate cooperative societies in the study area. Open-ended questions were used to elicit information on flood impacts and management, attitudes towards response measures and potential barriers were also addressed. Moreover, information on the inter-relationships between MSME actors and other stakeholders, such as local government officials, elected representatives, insurance companies and industry associations was also collected.

\section{MSME profile and owners' perspectives on floods and risk management}

In Mumbai and elsewhere in India, the majority of MSMEs operate from industrial estates ${ }^{4}$. They come together to form a cooperative society ${ }^{5}$ for the estate by forming a committee and contributing to the share capital. This committee and its appointed managers take care of day-today maintenance of the premises and common infrastructure. All decisions regarding contribution of individual MSME members, annual maintenance, structural changes, disputes among members and other issues pertaining to common areas and infrastructure are taken by the committee through consensus. Hence, all collaborative decisions and actions related to risk management and adaptation is the responsibility of the estate committee.

The MSME surveyed include manufacturing business engaged in engineering works, metal works, chemicals and paper products and printing; service centers, warehouses, businesses engaged in garment exports, interior designing, food products and transport services. Most industrial estates are 30 to 40 years old. The height of the adjoining roads and plots with new constructions near these estates has increased almost 3 to 5 feet during the last few decades. This has changed the rainwater run-off course, affecting the drainage pattern of industrial estates and channelizing the flow to these low-lying estates. Many estates also have to deal with water springs from the flooring of MSME units located on the ground floor. All study respondents (100\%) reported that their area gets flooded every year during monsoon. 54\% stated that floods occur at least 3 to 4 times every year, while 22\% reported experiencing floods 4 to 5 times a year. 12\% of MSME units stated that the frequency of floods in their area is 6 instances and more per year. MSME owners and their society representatives are vaguely aware that climate change may bring about variations in rainfall patterns in the future and that sea level rise may bring about more floods. However, they are generally not aware of the implications in terms of costs to their business operations and have not considered potential future impacts of such changes on their businesses and possible risk protection measures for the future.

The study found that although flood risk management is one of the key functions of the local authority (Municipal Corporation of Greater Mumbai (MCGM)), MSMEs have a strong distrust

\footnotetext{
${ }^{4}$ Industrial estate is a common area or site that houses a number of industrial units classified as SMEs that operate in similar or diverse businesses and co-exist for economies of scale in infrastructure facilities such as electricity, water, transport, banking, post office, canteen, etc.

${ }^{5}$ Cooperative society is a registered body under the Maharashtra Cooperative Societies Act 1960, where SMEs located in an industrial estate form the society and become members of it. Here, individual SMEs own the premises they operate from and the ownership of industrial estate (comprising common area and infrastructure) is vested with their cooperative society. Member SMEs make annual contribution to the cooperative society for performing various functions.
} 
towards the public sector to deliver essential services, including flood management. In low-lying areas, enhanced carrying capacity of storm water drainage network would help minimize the risks of floods. However, MSMEs do not have faith in the upgradation work, which is being undertaken by the local authorities. With limited flood management services and inadequate infrastructure provided by the municipal authorities, some MSMEs and industrial estates implement temporary measures for flood protection, such as the building of temporary barriers (small walls) outside business premises, shifting equipment and materials on higher ground, constructing platforms to elevate machinery, using dewatering pumps to drain floodwater etc. In many cases, the water pumped out of the industrial estates is simply released into adjoining drainage channels or next-door plot leading to serious maladaptation. They are not guided or supported by the local government or other agency to implement long-term solutions. As the measures applied are often temporary and ineffective during heavy precipitation, MSMEs suffer from significant impacts from floods and financial burden of losses. Moreover, as climate change is expected to worsen the risk of flash floods with changes in intensity, frequency and duration of rainfall, it is essential that MSMEs implement long-term solutions to build their adaptive capacity and resilience

For the businesses in Mumbai, it was found that - like everywhere else - size and geography constitute important determinants of risk exposure. Flood preparedness was thus found to differ across industrial estates depending on the type and size of businesses, flood experience, knowledge of flood management measures and the level of proactiveness of the estate managing committees. The study shows that the business case for proactive risk reduction and adaptation is obscured by a low capacity to respond and adapt. Interestingly, in contrast to common knowledge that access to finance is a main barrier for MSMEs, it was found that most industrial estate cooperative societies are in possession of an important corpus of funds that has been collected over last 30-40 years. Therefore for these estate cooperatives access to finance does not constitute an important barrier for investing in disaster risk reduction measures and thus for building adaptive capacity. Once their members are convinced of the benefits of implementing adaptation measures, they would be able to make the initial investment through this corpus. However, while this may hold true for old industrial estates in Mumbai, it is very likely that other estates, which are newly developed and located elsewhere, will not have the same access to funding. Based on the findings from the baseline survey, it was found that owners - when given appropriate information - were also willing to share the costs of investing in flood reduction measures and collectively design and implement measures through their cooperative societies. The low capacity to respond and adapt to floods is thus mainly due to a lack of awareness of the business rationale for engaging in risk reduction and of the possible measures available to them. Moreover, uncertainty about the extent and timing of climate change impacts is also found to constitute a key barrier.

Consequently, for MSME owners and cooperative managers to consider the potential of involvement in flood risk management, they need to be aware of the costs and benefits of investing in adaptation measures and what specific options are available to them. The baseline study thus shows that there is a clear case for raising MSMEs' and cooperative managers' awareness of the business rationale for engagement in flood risk reduction. Against this background, the next phase of the project was to develop a step-by-step framework to guide the 
implementation of effective long-term adaptation measures to allow for MSME actors to plan, design and implement risk reduction measures on their own.

\section{An innovative framework to manage flood risks}

While a number of useful tools and approaches have been developed to guide private sector actors' risk reduction actions and adaptation decision (see for example 'Climate Expert', GIZ; 'Aware for investment', Acclimatise; 'ND-Gain Country Index', University of Notre Dame), the baseline study showed that there is a clear need for specific guidance in the form of a tool that is adapted to the realities of MSMEs affected by flooding in an urban context like Mumbai. Some of the existing tools are very generic in their approach and often more suitable for bigger companies, that have the necessary skills and resources needed for applying the tools. To address this gap, a context and disaster specific hands-on tool to support MSME actors in planning and implementing risk reduction and adaptation measures was developed, in close collaboration with MSME managers and storm water- and structural experts. The step-by-step framework identifies data requirements, technical parameters and indicative structural and non-structural measures needed. A web-based toolkit was also developed to accompany the framework, and support the process of quantifying the costs and benefits of different measures for MSME representatives to achieve long-term flood resilience.

The key steps in the framework are shown in Figure 2 below.

\begin{tabular}{|l|l|}
\hline & - Problem assessment (data gathering \& data analysis) \\
\hline Step 3 & - Structural and non-structural measures \\
\hline Step 4 & - Financing options \\
\hline Step 5 & - Roadmap to implement measures \\
\hline
\end{tabular}

Figure 2: step-by-step operational framework for private sector funded resilience measures

For the purpose of this article, the focus is on the first three steps of the framework, which are presented in the following.

5.1 Problem assessment - The first step in designing the suitable flood resilience measures is to assess the nature of recurrent flooding and associated impacts on the industrial estate. Detailed analysis of impacts also helps in assessing how costs of the chosen measures would weigh against the potential benefits to the estates in terms of reduced loss and damage from flooding. Problem assessment includes collecting and analyzing information pertaining to the frequency, duration and depth of flooding in industrial estate; the possible causes of flooding; the types of 
losses and damages and quantification of these; the current response measures and their effectiveness. Data Analysis focuses on calculating the different type of losses, such as damage to physical structure (flooring, walls, windows, etc.), infrastructure (air conditioning and electrical systems, communication systems), loss due to suspension of production and loss of productivity due to absence of employees from work during flooding events. Typically MSMEs do not consider intangible losses from workers' absence, interrupted power supply and health impacts in their overall risk perception and assessment. However, when both intangible impacts are taken into account, flood impacts on MSMEs are found to be considerable.

5.2 Identification of key context-specific parameters - During the second the second step, characteristic key parameters for the estate are estimated to inform the identification and design suitable adaptation measures. These include rainfall intensity per hour, height of the estate vis-àvis surrounding plots ${ }^{6}$, total plot area and external plot area, connection with the municipal storm water drainage network, distance from the municipal storm water drain, nature and types of MSME businesses which are located on the ground floor and directly impacted by floods. Rainfall intensity per hour, external plot area and height of surrounding areas determine total water accumulation in the industrial estate. Connection and distance from municipal storm water drainage network determines where the estates can release floodwater. If the estate premises are not connected with municipal drains, different set of measures have to be implemented.

5.3 Structural and non-structural measures - Based on the above parameters and suitable assumptions about costs, etc., for the third step the study team designed structural and nonstructural measures and cost estimates in consultation with cooperative societies, as outlined in Table 2. Each measure is described in detail along with the technical requirements. All these measures have a lifetime of 25 years. Fixed and operating costs for each measure are approximate values estimated for assumed average values for different parameters. The innovative way in which these measures have been designed allows for context and locationspecific changes. By changing input values of the parameters, recommended structural measures, alone or in combination, can be customized by industrial estates to build flood resilience.

Investing in structural and non-structural adaptation measures was found to be beneficial for the case estates. In one of the Industrial Estate, investments were for example projected to generate net economic benefits after a seven year payback period, with increasing benefits over time.

\footnotetext{
${ }^{6}$ Most industrial estates in Mumbai are 25-35 years old and have seen heights of surrounding plots and adjoining roads increasing compared to their plots. This makes their plots low-lying compared to surrounding areas and more vulnerable to floods.
} 
Table 2: Recommended structural measures

\begin{tabular}{|c|c|c|c|}
\hline Measure & Description & $\begin{array}{l}\text { Technical } \\
\text { requirements }\end{array}$ & $\begin{array}{l}\text { Approx. fixed and } \\
\text { operating Costs }\end{array}$ \\
\hline $\begin{array}{l}\text { Cut off channel } \\
\text { at threshold }\end{array}$ & $\begin{array}{l}\text { Type of floor drain containing a channel } \\
\text { shaped body used for the evacuation of } \\
\text { surface water } \\
\text { Acts as a barrier for the flowing water to } \\
\text { enter the lo-lying }\end{array}$ & $\begin{array}{l}\text { - Channel size with specific } \\
\text { width and depth } \\
\text { Precast RCC cover of } \\
\text { specific thickness with drain } \\
\text { holes }\end{array}$ & $\begin{array}{l}\text { - } \quad \text { INR 400,000 (USD 6061) } \\
\text { fixed cost } \\
\text { - Maintenance not required } \\
\text { for next } 10 \text { years }\end{array}$ \\
\hline $\begin{array}{l}\text { Planned } \\
\text { surface } \\
\text { drainage and } \\
\text { SWD drains }\end{array}$ & $\begin{array}{l}\text { Constructing surface drainage and SWD } \\
\text { drains in the premises to remove the } \\
\text { excess water in the area }\end{array}$ & $\begin{array}{l}\text { Channel size with specific } \\
\text { width and depth } \\
\text { Precast RCC cover of } \\
\text { specific thickness with drain } \\
\text { holes } \\
\text { - } \\
\text { Adjusting surface slopes } \\
\text { where required }\end{array}$ & $\begin{array}{ll}\text { - } & \text { INR 8,500,000 (USD } \\
\text { 128,788) fixed cost } \\
\text { - } \quad \text { Maintenance not required } \\
\text { for next } 10 \text { years }\end{array}$ \\
\hline Sump tank & $\begin{array}{l}\text { - Capacity storage of approx. } 100,000 \\
\text { litres concrete water tank beneath the } \\
\text { ground }\end{array}$ & - $\quad$ Specific diameter and height & $\begin{array}{l}\text { - } \quad \text { INR 1,600,000 (USD } \\
\text { 24,242) fixed cost } \\
\text { - No maintenance as it is a } \\
\text { concrete tank }\end{array}$ \\
\hline $\begin{array}{l}\text { Dewatering } \\
\text { ring wells and } \\
\text { dewatering } \\
\text { pumps }\end{array}$ & $\begin{array}{l}\text { Dewatering well using cement concrete } \\
\text { rings as per the technical requirements } \\
\text { Specific number of rings to be placed } \\
\text { one on top of the other after excavation } \\
\text { Gap between two rings not to be sealed } \\
\text { to facilitate sub-surface ground water to } \\
\text { enter the dewatering well even during } \\
\text { dry season } \\
\text { Pumping of water in the well using } \\
\text { dewatering pump would help to keep } \\
\text { ground water at a lower level so that no } \\
\text { spring effect occurs in industrial sites on } \\
\text { the ground floors }\end{array}$ & $\begin{array}{ll}- & \text { Rings of specific diameter } \\
\text { and depth } \\
\text { - } \quad \text { Total number of rings } \\
\text { Dewatering pump with } \\
\text { specific capacity measured } \\
\text { in litres per minute }\end{array}$ & $\begin{array}{l}\text { - } \quad \text { INR 1,000,000 (USD } \\
\text { 15,152) of fixed cost } \\
\text { NR 5,000 (USD 76) for } \\
\text { overhauling of pump } \\
\text { annually }\end{array}$ \\
\hline $\begin{array}{l}\text { Ground water } \\
\text { cut off walls }\end{array}$ & $\begin{array}{l}\text { - } \quad \text { Contaminated ground water can cause } \\
\text { damage to building foundations, load } \\
\text { bearing columns etc. } \\
\text { Infiltration of sub-surface water from } \\
\text { surrounding areas e.g. sea front, beach } \\
\text { areas, or nullahs (urban streams formed } \\
\text { due to rainwater flow, or overflow of } \\
\text { lakes during monsoon, carrying wastes - } \\
\text { both solid and liquid) into industrial } \\
\text { areas } \\
\text { Construct a retaining wall between the } \\
\text { source of seepage or infiltration and the } \\
\text { source of ultimate damage }\end{array}$ & $\begin{array}{l}\text { High Density Polyethylene } \\
\text { (HDPE) liner and gravels } \\
\text { inside to fill the hollow part }\end{array}$ & $\begin{array}{ll}\text { - } & \text { INR 100,000 (USD 1,515) } \\
& \text { fixed cost } \\
\text { - } & \text { No maintenance required }\end{array}$ \\
\hline Recharging pit & $\begin{array}{l}\text { - } \quad \text { Recharging pit comprising honeycomb } \\
\text { brick walls, interfaced with existing } \\
\text { borewell through micro tunneling } \\
\text { - When water fills in this pit and starts } \\
\text { rising, it will flow through the micro } \\
\text { tunnel into the borewell } \\
\text { - Using submersible pumps, water from } \\
\text { borewell can be drawn to use for } \\
\text { industrial purpose. } \\
\text { - The water holding capacity of this } \\
\text { filtration pit would be about } 10,000 \\
\text { litres. }\end{array}$ & - $\quad$ Specific diameter and depth & $\begin{array}{l}\text { - } \quad \text { INR 50,000 for one } \\
\text { recharging pit as fixed cost } \\
\text { Maintenance INR 2,500 } \\
\text { annually }\end{array}$ \\
\hline
\end{tabular}


In addition to structural measures to help industrial estates protect their premises from current and future flood risks, non-structural measures, as depicted in Table 3, such as awareness raising, development of early warning system, emergency planning and improved solid waste management are proposed. These all have direct and/or indirect bearing on how effectively businesses can deal with flood risks.

\section{Table 3: Recommended non-structural measures}

\begin{tabular}{|c|c|c|c|}
\hline $\begin{array}{l}\text { Early Warning } \\
\text { System }\end{array}$ & $\begin{array}{l}\text { A tipping bucket rain } \\
\text { gauge with sensor } \\
\text { connected to computer will } \\
\text { collect data every fifteen } \\
\text { minutes. }\end{array}$ & $\begin{array}{ll}\text { - } & \text { INR 40,000 (USD } \\
\text { 600) fixed cost } \\
\text { - } \quad \text { INR 2,000 (USD } \\
\text { 30) for annual } \\
\text { maintenance }\end{array}$ & 7-8 years \\
\hline $\begin{array}{l}\text { Emergency } \\
\text { planning \& SOP }\end{array}$ & $\begin{array}{l}\text { SOP guides to every SME } \\
\text { unit \& flyers with } \\
\text { immediate steps }\end{array}$ & $\begin{array}{l}\text { - INR 25,000 (USD } \\
\text { 375) fixed cost }\end{array}$ & $\begin{array}{l}5 \text { years (updated } \\
\text { after } 5 \text { years) }\end{array}$ \\
\hline $\begin{array}{l}\text { Solid Waste } \\
\text { Management }\end{array}$ & $\begin{array}{l}\text { House Keeping will take } \\
\text { care of waste on a daily } \\
\text { basis, only dust bins, } \\
\text { gloves \& other essentials } \\
\text { need to be bought }\end{array}$ & $\begin{array}{l}\text { - } \quad \text { INR 40,000 (USD } \\
\text { 600) fixed cost for } \\
\text { equipment } \\
\text { INR } 75000 \text { (USD } \\
\text { 1150) operating } \\
\text { cost annually for } \\
\text { housekeeping staff }\end{array}$ & $\begin{array}{l}2-3 \text { years for } \\
\text { housekeeping } \\
\text { equipment }\end{array}$ \\
\hline $\begin{array}{l}\text { Awareness } \\
\text { building }\end{array}$ & $\begin{array}{l}\text { Brochures \& workshop } \\
\text { expenses in which a } \\
\text { disaster management } \\
\text { professional will carry out } \\
\text { the session }\end{array}$ & $\begin{array}{l}\text { - INR 15,000 (USD } \\
\text { 225) fixed cost }\end{array}$ & $\begin{array}{l}\text { Awareness } \\
\text { campaign every } \\
2-3 \text { years }\end{array}$ \\
\hline
\end{tabular}

The above mentioned structural and non-structural measures may in certain cases be implemented separately; in other cases they will only be effective when applied in combination, depending on the specific context. Key to the framework is the need for business owners' risk perception to be based on actual losses and damages from floods. Only with the demonstration of a clear business case for engagement in flood risk management engagement, will long-term risk reduction and adaptation measures be implemented.

\section{Conclusion}

Little is yet known about the bottom-line repercussions of risk reduction and adaptation strategies implemented by firms (Pauw \& Pegels, 2013) and the kind of measures that are available and suitable for different contexts. To address this gap, studies have drawn attention to the need to further develop methodologies and tools for identifying and assessing adaptation strategies in a context of high uncertainty (Lempert \& Groves, 2010). To contribute to develop this area and unpack the rationale for - and the avenues through which - MSMEs may implement 
risk reduction measures, the present study has provided empirically-based insights from MSMEs impacted by recurrent flooding in Mumbai.

The study has shown that over the last ten years, frequent flooding from extreme precipitation has recurring negative impacts for industrial estates, where MSMEs are suffering from large annual or sometimes multi-annual damages. The study found that although there are limited direct short term financial incentives for MSMEs to invest in adaptation measures, the cost of inaction is substantial in the long term, when indirect impacts and costs are also taken into account. There is thus a clear case for applying a longer-term perspective to MSMEs' flood risk assessments. The benefits estimated through the proposed framework can provide a convincing argument for industrial estate committees and MSME owners to prioritize the implementation of flood resilience measures. The approach and framework developed through this study is expected to provide a structured entry-point to create greater awareness of the business rationale for engagement in flood resilience and an understanding of the processes needed to initiate adaptation initiatives from a business perspective.

In conclusion, this study demonstrates the need to encourage private sector participation in adaptation efforts, also in the case of smaller actors such as MSMEs. Irrespective of their size, there is a strong case for private sector actors to design, finance and implement suitable adaptation measures to build their long-term flood resilience. It was found that it makes business sense for MSMEs to participate collaboratively in this effort, given the benefits that would accrue from the short- to the long-term. The findings may provide a case example for other industrial estates and MSMEs to follow and there is thus great potential to adopt this approach and replicate it for different end-users and in different contexts. This approach provides a unique opportunity to identify locally designed solutions for local problems, rather than relying on a topdown approach where government and other entities prescribe solutions that may not be appropriate to the context and setting of the local users. The results from this study thus provide an opportunity for further work on developing and adapting frameworks to assess adaptation costs, benefits and suitable measures, which support risk reduction actions by small firms in diverse geographical contexts and for different types of disasters.

To make the approach relevant and replicable for MSMEs in different sectors as well as upscalable in other geographical contexts, it is essential to capture relevant context specificities in the development of such approaches. This is a resource intensive exercise, which would therefore require a strong institutional mechanism or policy push to promote flood resilience among MSMEs and industrial estates. Industry associations may for example play an important role in creating awareness about the application of potential structural and non-structural measures by industrial estates, to build long-term flood resilience. Moreover, a policy push from the government in the form of incentives to new industrial estates or the inclusion of flood resilience in building codes also constitutes a key element in support of the adoption of resilience building measures by private sector players. 


\section{Bibliography}

Agrawala, S., Carraro, M., Kingsmill, N., Lanzi, E., \& Prudent-richard, G. (2011). Private Sector Engagement in Adaptation to Climate Change. OECD Environment Working Paper No 39.

Barros, V. R., Field, C. B., Dokken, D. J., Mastrandrea, M. D., Mach, K. J., Bilir, T. E., ... White, L. L. (2014). Climate Change 2014: Impacts, Adaptation, and Vulnerability. Part B: Regional Aspects. Contribution of Working Group II to the Fifth Assessment Report of the Intergovernmental Panel on Climate Change. Cambridge, U.K., and New York, N.Y., U.S.A.

Berkhout, F., Hertin, J., \& Gann, D. M. (2006). Learning to adapt: Organisational adaptation to climate change impacts. Climatic Change, 78(1), 135-156. http://doi.org/10.1007/s10584006-9089-3

Dougherty-Choux, L., Terpstra, P., Kurukulasuriya, P., \& Kammila, S. (2015). Adapting from the ground up, WRI, UNDP.

Field, C.B., Barros, V., Stocker, T.F., Qin, D., Dokken, D.J., Ebi, K.L., Mastrandrea, M.D., Mach, K.J., Plattner, G.-K., Allen, S.K., Tignor, M., Midgley, P.M., 2012. Managing the Risks of Extreme Events and Disasters to Advance Climate Change Adaption. A Special Report of Working Groups I and II of the Intergovernmental Panel on Climate Change. Cambridge University Press, New York.

GIZ, \& SIDBI. (2013). Facing the Impacts of Climate Change: Indian MSMEs and Adaptation. New Delhi.

Haigh, N., \& Griffiths, a. (2012). Surprise as a Catalyst for Including Climatic Change in the Strategic Environment. Business \& Society, 51(1), 89-120. http://doi.org/10.1177/0007650311427425

IPCC, 2014. Climate Change 2014: Impacts, Adaptation, and Vulnerability. Part B: Regional Aspects. Contribution of Working Group II to the Fifth Assessment Report of the Intergovernmental Panel on Climate Change, (Barros, V.R., C.B. Field, D.J. Dokken, M.D. Mastrandrea, K.J. Mach, T.E. Bilir, M. Chatterjee, K.L. Ebi, Y.O. Estrada, R.C. Genova, B. Girma, E.S. Kissel, A.N. Levy, S. MacCracken, P.R. Mastrandrea, and L.L. White (eds.)]. Cambridge University Press, Cambridge, United Kingdom and New York, NY, USA, 688 pp.

Linnenluecke, M. K., Griffiths, A., \& Winn, M. (2012). Extreme weather events and the critical importance of anticipatory adaptation and organizational resilience in responding to impacts. Business Strategy and the Environment, 21(1), 17-32. http://doi.org/10.1002/bse.708

MCGM (2014). Greater Mumbai City Development Plan 2005 to 2025. Available at http://www.mcgm.gov.in/irj/portal/anonymous?NavigationTarget=navurl://095e1c7b9486b 1423b881dce8b106978

MCGM, (2015), Flood Preparedness Guidelines 2014, Disaster Management Unit, Municipal Corporation of Greater Mumbai

Nicholls, R. J., Hanson, S., Herweijer, C., Patmore, N., Hallegatte, S., Corfee-Morlot, J., ... Muir-Wood, R. (2008). Ranking Port Cities with High Exposure and Vulnerability to Climate Extremes: Exposure Estimates (Environment Working Papers No. 1). Paris.

Okereke, C., Wittneben, B., \& Bowen, F. (2012). Climate change: challenging business, transforming politics. Business \& Society, 51(1), 7-30. 
Patankar, A., Patwardhan, A., (2016), Estimating the uninsured losses due to extreme weather events and implications for informal sector vulnerability: a case study of Mumbai, India, Natural Hazards: Journal of the International Society for the Prevention and Mitigation of Natural Hazards, 80, issue 1, p. 285-310.

Ranger, N., Hallegatte, S., Bhattacharya, S. et al. Climatic Change (2011) 104: 139.

Schiller, A., de Sherbinin, A., Hsieh, W-H., Pulsipher, A., 2007. The Vulnerability of Global Cities to Climate Hazards. George Perkins Marsh Institute, Clark University, Center for International Earth Science Information Network (CIESIN), Columbia University

UNEP 2016. The Adaptation Finance Gap Report 2016. United Nations Environment Programme (UNEP), Nairobi, Kenya

UN-HABITAT, 2016. World Cities Report. UN-Habitat HS Number: HS/038/16E No of Pages: 262 ISBN Series Number: 978-92-1-133395-4

United Nations Global Compact (UNGC). (2015). The Business Case for Responsible Corporate Adaptation: Strengthening Private Sector and Community Resilience A Caring for Climate Report.

Wedawatta, G., Ingirige, B., \& Amaratunga, D. (2010). Building up Resilience of Construction Sector SMEs and Their Supply Chains to Extreme Weather Wvents. International Journal of Strategic Property Management, 14(4), 362-375. 